\title{
Anomalies in the Sintra National Palace wood-framing
}

Received (in revised form): 6th July, 2006

\section{Jorge de Brito}

graduated in Civil Engineering and received his Masters and Doctoral degrees at IST - Technical University of Lisbon, Portugal, where he is an associate professor. He is a member of IABSE, FIB, CIB and IABMAS, as well as of several reputed national engineering societies. He is a member of the following working groups: CIB W80/RILEM 100-TSL - Service Life Prediction of Building Materials and Components; CIB W86 - Building Pathology; CIB TG39 - Deconstruction; several national committees under CEN. His research work deals with deterioration, rehabilitation and management of concrete structures. He has co-authored the 'Handbook of Concrete Bridge Management', published by ASCE Press in 2004.

\section{Vítor Sousa}

is MSc in Construction and Research Assistant at ESTB - Polytechnic of Setúbal. His research is related with inspection and maintenance of historical buildings and in situ tests.

\section{Telmo Dias Pereira}

graduated in Civil Engineering and received his Masters and Doctoral degrees at FCTUC - University of Coimbra, Portugal, where he is an assistant professor. His research work deals with inspection and maintenance, rehabilitation of historical buildings.

Correspondence: Jorge de Brito, Department of Civil Engineering and Architecture, Section of Construction, IST - Technical University of Lisbon, Av. Rovisco Pais, Lisbon 1049-001, Portugal; Tel: + 351 218419709; Fax: + 35121 8497650; E-mail: jb@civil.ist.utl.pt

\begin{abstract}
The National Palace of Sintra in Portugal is a multi-storeyed national monument that portrays architectural/historical styles from the 13th to 19th centuries. The contribution of its many ancient wood-framing elements to its image is paramount. Generally, the assessment of historical buildings is focused mainly on (a) structural features concerning the brick or stone walls and the wooden floors, or (b) highly valued decorative features such as frescoes, stuccos and façades detailing. Other elements such as window and door panels, verandas, foot panels and staircases are less frequently referred to even though their degradation mechanisms are many and complex. In this paper, the causes for deterioration of wood-framing are thoroughly described and their relative weight in the overall degradation is commented upon. A grading system for the degradation of wood-framing is proposed and the maintenance/rehabilitation/ replacement measures better adapted to each level of degradation are described. A survey made of the wood-framing of the National Palace of Sintra is presented and thoroughly illustrated and some conclusions are drawn from its results.
\end{abstract}

Journal of Building Appraisal (2006) 2, 193-206. doi:10.1057/palgrave.jba.2950038

\section{Keywords:}

wood-framing, deterioration mechanisms, National Palace of Sintra, survey

\section{INTRODUCTION}

As a secondary element, wood-framing is frequently forgotten and seldom referred to in written references. Given its roles (a barrier between the outer and the inner space, ventilation, illumination), its intrinsic characteristics (heterogeneous constitution, small 
depth and reduced mechanical strength) and the actions it is subjected to, however, it undergoes a precocious degradation as compared with that of the surrounding elements (namely the walls).

The National Palace of Sintra in Portugal (Figure 1) is one of Portugal's most important monuments and dates from prior to the birth of the nation (12th century). Kings were born and died within it and it was for several centuries the centre of the kingdom's government. It incorporates architectural styles of various historical periods and is the second most visited tourist site in Portugal. In terms of its wood-framing, various existing elements can and should be viewed as historical or even archaeological objects. As a matter of fact, at the time of the 1755 earthquake the use of glass panels to fill woodframing was reserved to few of the more important buildings as they were imported from France or England and hence very expensive. Therefore, doorways and peep-windows were used, fitted behind the window-opening.

Besides enveloping this history that is lost nowadays due to the generalised replacement of wood-framing with modern metallic and synthetic framing, the woodframing plays an important role in the identity of the court, in its day-to-day living and interpretation of the inner spaces and, especially, in the protection it provides to the invaluable historical pieces within. These are motives enough to give special attention to its maintenance, and especially to that of the envelope wood-framing.

\section{MAIN CAUSES OF DEGRADATION}

Fire is undoubtedly the most destructive force concerning wood-framing. But there are other causes of degradation that are more frequent and generalised such as dampness, ultraviolet radiation, moulds, fungi (namely rot fungi), xylophagous organisms and lack of adequate maintenance. The degradation of wood-framing originates by phenomena of physical, chemical, mechanic or biological nature either in isolation or, in most cases, simultaneously with at least one other (Stahl, 1980; National Laboratory of Civil Engineering (LNEC), 2003).

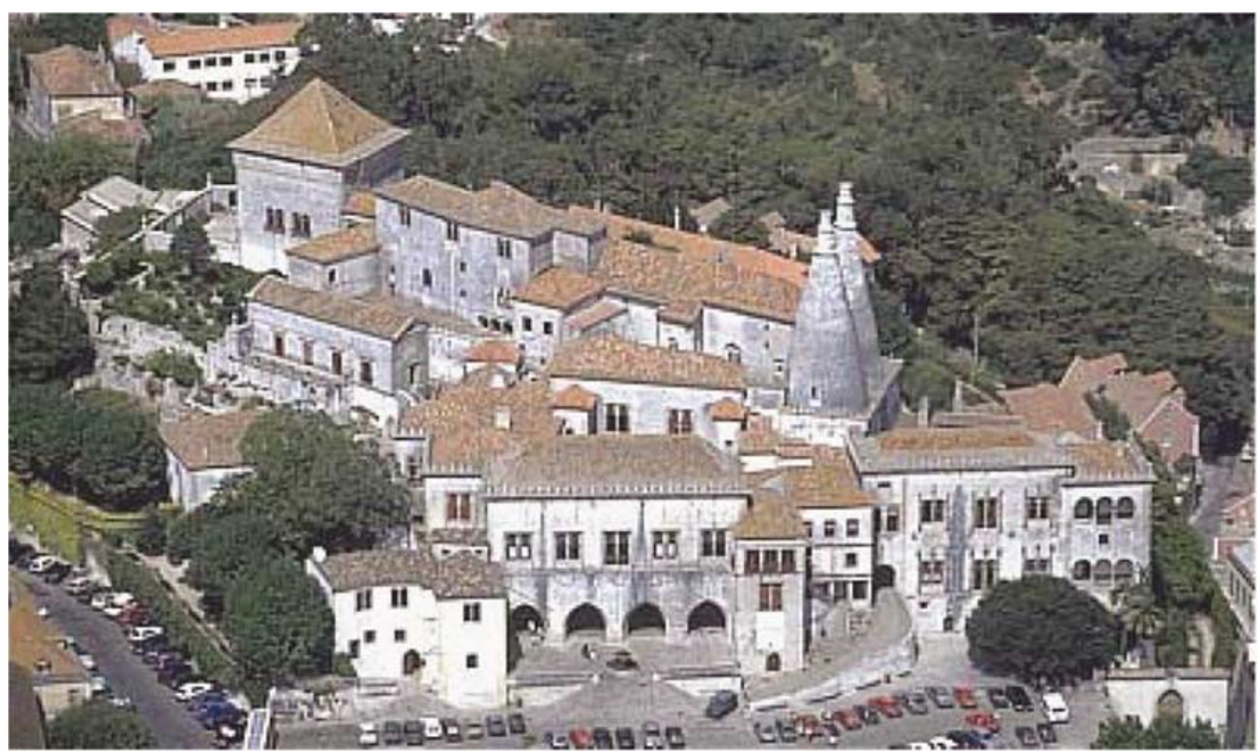

Figure I: Aerial view of the Sintra National Palace 
Dampness in its various shapes is the biggest cause of degradation of wood-framing, mostly in the façades, due to its direct action in conjunction with other environmental factors such as ultraviolet radiation or indirectly by providing the right conditions for the development of moulds and rot fungi (Richardson, 1980; Aguiar et al., 1997). In Table 1, the risk of attack from each biological agent is related with the timber exposure conditions and its consequent moisture content (wood-framing belongs to risk class 3 ).

\section{Dampness}

Of the various ways dampness can affect wood-framing, rain is clearly the most relevant. The penetration of rain within wood-framing elements occurs preferentially through damaged or unprotected areas, inadequate or deteriorated painting or veiling systems, or due to the hygroscopicity of the material itself.

In the linings of the window-openings, it is still frequent that dampness penetrates through the usually unprotected surfaces in contact with humid walls or masonry. This occurs more frequently in ground floors or in locations that communicate with areas where water accumulation is possible, such as verandas, terraces or patios.

Variations in the moisture content of wood-framing elements give rise to swelling and shrinking that are responsible for deficiencies in their functioning and watertightness that are more or less significant according to the level of moisture content (dimensional variations in timber elements occur only for values below 24 per cent, the average value of fibre saturation (Nero, 2002)). Under these conditions, crushing of elements may occur, usually in the lower joints, with significant deterioration mostly of paint and veiling but in extreme cases with fracture or dislocation of other elements.

These moisture content variations are also at the origin of cracking, bowing and various distortions, discoloration and leaching of painting and veiling systems and subsequent discoloration, erosion and disintegration of the exposed timber surface.

Pathological situations arising from construction and condensation dampness and mostly hygroscopicity of the wood, however, cannot be ruled out, especially in interior wood-framing where the influence of rain is not felt (Richardson, 1980, 1991).

The moisture content due to timber hygroscopicity is a function of the air temperature and relative humidity. Therefore, given these two parameters, it is possible to estimate the moisture content using a Keylwerth diagram (Figure 2) that was established from the experimental results of R. Keylwerth in the 1950s and 1960s.

Table I: Risk classes for solid timber

\begin{tabular}{|c|c|c|c|c|c|c|}
\hline \multirow{2}{*}{$\begin{array}{l}\text { Risk } \\
\text { classes }\end{array}$} & \multirow[t]{2}{*}{ General in-service situations } & \multirow{2}{*}{$\begin{array}{l}\text { Exposure } \\
\text { to dampness }\end{array}$} & \multirow{2}{*}{$\begin{array}{l}\text { Timber moisture } \\
\text { content (\%) }\end{array}$} & \multicolumn{3}{|c|}{ Main biological agents } \\
\hline & & & & Wood-worms & Termites & Fungi \\
\hline I & $\begin{array}{l}\text { No contact with soil, under } \\
\text { cover (eg pavements) }\end{array}$ & None & Maximum 20 & ++ & + & - \\
\hline 2 & $\begin{array}{l}\text { No contact with soil, under } \\
\text { cover but with risk of } \\
\text { dampening (eg roof structures) }\end{array}$ & Occasional & Occasionally >20 & ++ & + & $++*$ \\
\hline 3 & $\begin{array}{l}\text { No contact with soil, no cover } \\
\text { (eg wood-framing) }\end{array}$ & Frequent & Frequently $>20$ & + & ++ & $+++\dagger$ \\
\hline 4 & $\begin{array}{l}\text { In contact with soil or fresh } \\
\text { water (eg foundations, poles) }\end{array}$ & Permanent & Permanently > 20 & + & +++ & $+++^{\ddagger}$ \\
\hline 5 & $\begin{array}{l}\text { Under salt-water } \\
\text { (eg pontoons) }\end{array}$ & Permanent & Permanently $>20$ & \multicolumn{3}{|c|}{ Maritime xylophagous organisms } \\
\hline
\end{tabular}

*Brown rot, ${ }^{\dagger}$ Brown and white rot, ${ }^{\ddagger}$ Brown, white and soft rot.

Note: +++ High; ++ Average; + Low; -Nil. (LNEC, 2003; [I I]Nunes, 200I). 


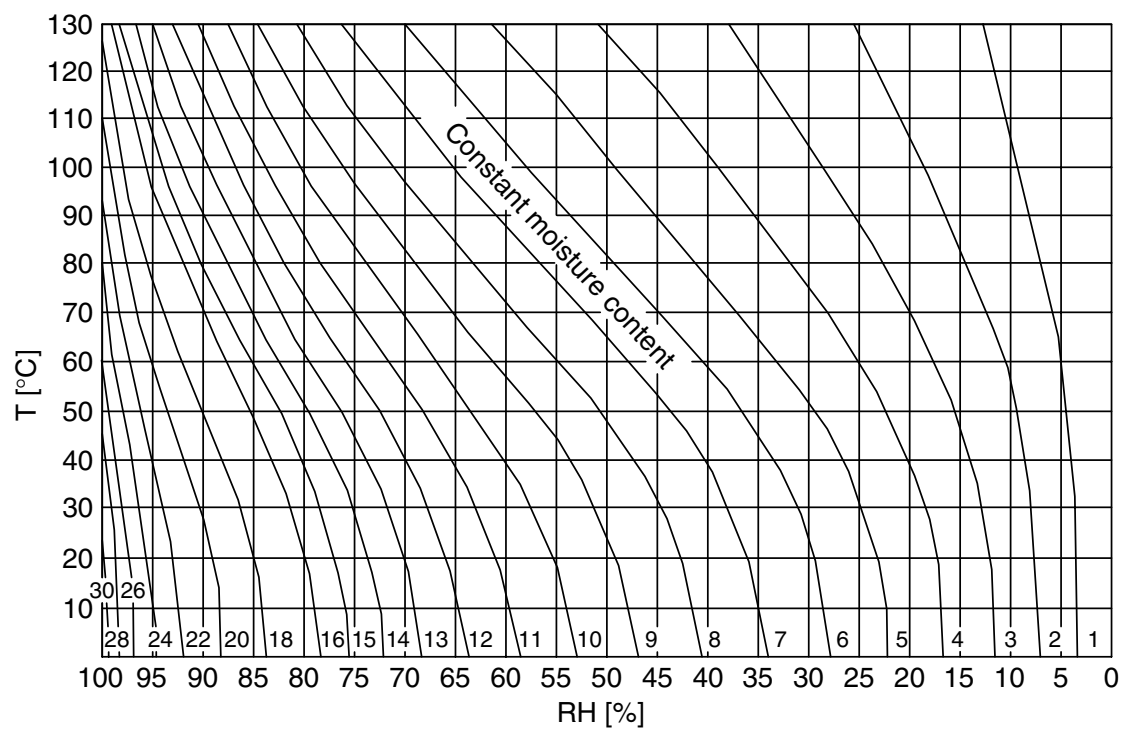

Figure 2: Keil diagram. T - temperature, $\mathrm{HR}$ - air relative humidity Source: www.thermolignum.com

Taking into account the values registered in the rain gauge at Sintra/Vila, the average humidity content may vary, just because of hygroscopic phenomena, from 16 per cent in July to values above 20 per cent in the months of December and January. This seasonal change of the timber moisture content is responsible for significant dimensional variations of the interior wood-framing (in outer wood-framing the dampness due to rain is much more important), thus resulting in functioning deficiencies, bowing and cracking. The high moisture content is also responsible for promoting growth of moulds and fungi (Department of the Environment (DE), 1989; Aguiar et al., 1997).

Dampness in association with atmospheric oxygen is also responsible for corroding metallic elements of the wood-framing.

\section{Temperature}

Thermal degradation of wood-framing is highlighted by loss of strength, mass and dimensional stability. The most relevant degradation from temperature variations in wood-framing, however, occurs when waterproof protections are applied. In these cases, the accumulation of moisture on the timber surface (underneath the protection) is frequent due to the evaporation and condensation of the timber moisture under the action of atmospheric thermal fluctuations and especially due to the difference of temperature between the inner and the outer space, causing thermal gradients within the timber elements. This phenomenon in itself does not generally result in deterioration of the wood-framing but the local increase in the timber moisture may reach levels that are compatible with the development of fungi.

High levels of moisture within the timber may arise from the use of green timber with excessive moisture contents (over 12 per cent) resulting from incomplete drying, application of protections (painting or veiling) in humid weather or defects in the protection of the elements (Richardson, 1980).

\section{Radiation}

The radiation responsible for wood-framing deterioration is localised within the ultraviolet spectrum. Besides being responsible for timber discoloration, ultraviolet 
radiation degrades the protections, painting and veiling systems, and the putties through the loss of plasticity, making them brittle.

The direct action of ultraviolet radiation induces the decomposition of the timber organic compounds, such as the lignin hydrolysis (the 'glue' that sticks the timber fibres together) caused by the simultaneous action of ultraviolet radiation and water. This decomposition is structurally insignificant and is limited to a surface layer of the elements, less than $5 \mathrm{~mm}$ deep, but is responsible for the initial tanning of the timber, resulting in a darker shade of the original colour (Richardson, 1980; Nunes, 2001).

In the case of elements exposed to rain, leaching of the outer layer of lignin occurs, thus accelerating the erosion process and changing the timber colour from brown in dry environments to grey in humid environments, depending on the species. The leaching caused by the simultaneous action of solar radiation (in the ultraviolet spectrum) and rain (usually referred to as weathering) makes the surface rough and slightly friable, which impairs the application of painting systems, making it necessary to remove this superficial layer (Morris, 1998; Williams, 1999).

\section{Wind}

Wind action may be responsible for the fracture of the slenderest timber elements or glass plates by bending and ironwork deformation. By dragging solid particles, it is also responsible for surface erosion and defects in the wood-framing finishing. Indirectly or in conjunction with temperature, wind is responsible for pressure gradients between the inside and the outside of buildings and, in big buildings such as the National Palace of Sintra, between inner spaces, causing air drafts that may damage the wood-framing (Aguiar et al., 1997).

\section{Moulds}

Moulds grow in various organic materials as long as they find the appropriate humidity conditions. In wood-framing they are frequent in humid and poorly ventilated locations both in the exposed and painted surfaces. The anomalies caused by moulds are associated only to non-structural elements of the timber and have an aesthetical nature resulting from green, grey, black and occasionally yellow stains that cause a slight superficial discoloration of the timber. Furthermore, the spores produced by the moulds may cause respiratory problems in sensitive persons (Morris, 1998).

The development of moulds depends on the quality and proprieties of the timber as well as on the treatment it has been subjected to and the coating used. Environmental conditions are, however, determinant in terms of risk and relative growth of the moulds (Figure 3).

\section{Fungi}

The fungi that affect wood-framing may be divided in two main types, chromogenic fungi and rot fungi. Chromogenic fungi only cause stains in timber and do not generally affect its structural strength. They can be divided in two types (Morris, 1998):

- those that manifest themselves in green timber, recently cut with high moisture contents (usually referred to as sap stain);

- and those that grow under the timber protections (painting and veiling systems or varnishes) due to dampness accumulations (usually referred to as blue stain). 


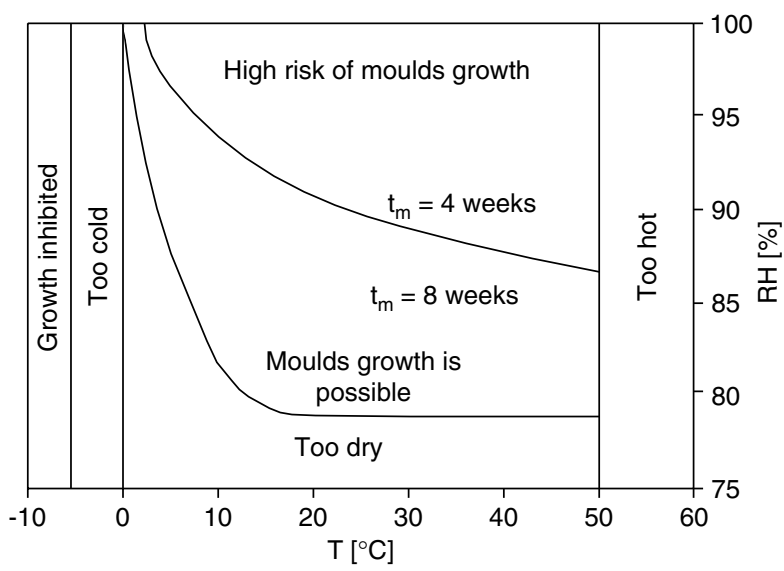

Figure 3: Time needed for moulds to grow as a function of air temperature $(\mathrm{T})$ and relative humidity $(\mathrm{RH})$ Source: Vittanen (2002)

The latter ones are able to penetrate through the paint layers and their pigmentation protects them from ultraviolet radiation. Some are also able to grow on products resulting from the decomposition of timber lignin by UV's (Morris, 1998).

Out of the chromogenic fungi that occur in green timber, those of the genus Ceratostomella must be highlighted since they are the main cause of blue stain, one of the most common defects in pine. These fungi strike during the drying of the timber when the moisture content reaches $25-30$ per cent and air temperature is around $22^{\circ} \mathrm{C}$. They attack the reserve substances contained within the parenchyma cells of the stem and therefore the mechanical strength is not affected, except for impact resistance (Saraiva, 1957a).

When timber dries, the activity of this type of fungi ceases and they remain inactive until the moisture content recovers. When there are good conditions for their development of rot fungi, Ceratostomella is rapidly replaced by them (LNEC, 1967, 1968).

Given intermediate moisture content (over 18-20 per cent) and the presence of oxygen, there are conditions for the development of rot fungi responsible for the gravest degradation in timber. This type of fungi is known as basidiomycetes, and they are divided in terms of the way they degrade timber in (Richardson, 1980):

- White rot, that results from fungi that feed on lignin and cellulose making timber white and spongeous; this type of fungus is more frequent in hardwoods, such as oak, and the loss of strength is comparatively slower;

- Brown rot, that results from fungi that feed only on cellulose, leaving intact the remains of lignin, thus making the brown timber brittle; this type of fungi tends to affect softwoods, such as pine; in Figure 4 an example is presented of the lintel of an inner door of the National Palace of Sintra contaminated with brown rot fungi.

Fungi can also be classified in terms of the humidity level needed for its development. The fungi capable of developing in timber with low moisture content, such as Merulius lacrymans (known as dry rot), ought to be highlighted since after installation they are able to produce water through the digestion of timber thus keeping the environment relatively humid in poorly ventilated locations. Furthermore, this type of fungi is able to develop filaments that conduct water and nutrients, allowing them to spread over inhospitable surfaces in search of more timber (Richardson, 1980; Stahl, 1980). 

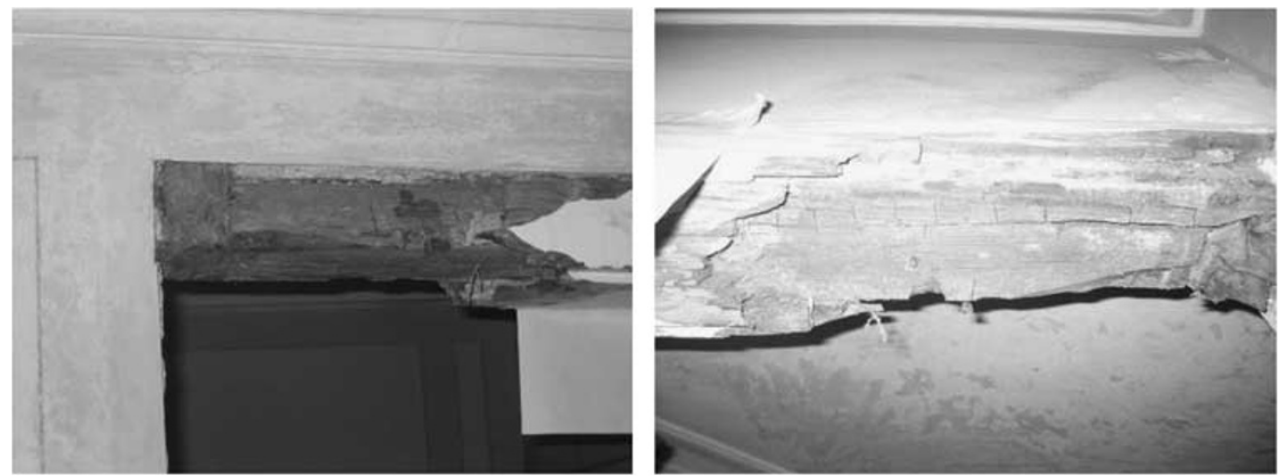

Figure 4: Examples of brown rot of the lintel of an inner door

There is still another type of fungi responsible for significant degradation in timber elements, denominated soft-rot fungi. This type of fungi is closely related with moulds and stain-causing fungi and has the capacity of breaking the lignin apart, thus softening the wood. Typically, these fungi grow in permanently wet timber, in a relatively slow process from the surface to the centre. Visually timber remains intact with only small cracks along and through the dry timber grain. This type of fungi is more frequent in elements located in maritime environment, such as boats and pontoons, or in contact with soil, and therefore it does not usually occur in wood-framing, except in extreme situations of framings that are in contact with soil due to design or construction defects or rising of the pavements level (Saraiva, 1957a; Mateus, 1978).

\section{Bacteria}

Damp timber tends to be colonised by bacteria. They may simply live inside the nonstructural elements of timber, causing an increase in its permeability, or be capable of degrading lignin or cellulose even in timber treated with preservatives. Degradation caused by bacteria is insignificant in most cases. Bacteria, growing in similar conditions to chromogenic fungi, however, make the timber surface more porous, allowing faster water absorption and thus favouring the development of other types of fungi that are more aggressive to timber (Richardson, 1991).

\section{Xylophagous insects}

By opening galleries inside the timber, xylophagous insects are responsible for significant losses of strength, mostly in the slenderest elements made essentially of sapwood. In Portugal, the most common and damaging xylophagous insects are wood-worms and, in a lesser scale, termites (LNEC, 1967, 1968; Mateus, 1978).

The larvae of the bigger species of woodworm (Hylotrupes bajulus) destroy only the sapwood of coniferous wood, such as pine, in a process that may take various dozens of years depending on the feeding conditions, temperature and moisture content of the timber (Saraiva, 1957b).

The smaller wood-worm (Anobium punctatum and Nicobium castaneum) attacks the pith and the sapwood of coniferous and deciduous species, with an emphasis on the latter. Sometimes it comes up in areas in which the beginning of decomposition by fungi has occurred (Stahl, 1980).

'White ant' (Reticulitermes lucifugus) is an underground ant that attacks damp timber, especially that in contact with ground floor mortars, foundations, masonry or ground-floor 
walls. It grows easily in any timber that presents a moisture content favourable to the development of fungi, even though it can sometimes be found in timber only slightly damp (Saraiva, 1957b; Richardson, 1980).

\section{Normal use/tourism}

Most wood-framing includes mobile elements consequently subjected to natural wear from normal and accidental use. In the particular case of the National Palace of Sintra, tourism is the most intense use of the space in general which translates also into a more intense use of the wood-framing. Tourism implies the use of the space by people of very variable cultural level and age, resulting in damage from negligence or even neglect.

\section{Vandalism}

Vandalism of the wood-framing usually translates as broken glass due to stone throwing or intrusion attempts. The fact that barracks of the National Republican Guard exist in the backyard of the Sintra National Palace reduces the incidence of vandalism.

\section{Pollution}

Degradation of the wood-framing caused by pollution is very rare and under normal circumstances is associated with their exposure to gases resulting from burning combustible fossils. The combination of sulphur and nitrogen oxides within the gases with water gives rise to acids that cause the hydrolysis of the timber cellulose and the separation of the fibres at the surface. Typically, the superficial layer of the timber becomes smoother and a paper pulp comes up looking like a white 'vegetation' (more frequently brownish due to the gases), which is frequently mistaken for fungi.

These anomalies are insignificant from a structural point of view but the timber affected is more difficult to paint. Atmospheric pollution is still responsible for aesthetic anomalies resulting in the darkening of wood-framing painting (Richardson, 1991).

\section{ANOMALIES SURVEY OF SINTRA NATIONAL PALACE}

Wood-framing anomalies are usually classified in terms of the intervention level they require and the following cataloguing in three categories is frequent (Myers, 1981):

- routine maintenance;

- stabilisation;

- elements replacement.

Wood-framing included in the first category are in a good state of general conservation, showing signs only of some natural wear of the internal and external painting and of the glasses putty, due mostly to climate-related actions and use. Generally, the wood-framing rehabilitation comprehends the following phases:

- removal of some layers of paint;

- removal of the deteriorated putty;

- eventual repairs of the wood-framing and its lining;

- application of putty and paint.

Wood-framing that already presents some physical degradation of its elements is included in the second category. In these cases, the extent of the degradation is reduced but the 
stabilisation of the wood-framing is still viable through rehabilitation, patching and/or consolidation of the deteriorated elements. Intervention at this level consists generally in:

- removal of paint and putty;

- drying of timber;

- treatment with fungicide of the areas attacked by fungi or insects;

- application of two or three coats of a prime based on boiled oil (time between coats application must be at least $24 \mathrm{~h}$ );

- filling of the cracks and holes with putty;

- final painting after light sand-papering in order to roughen the surface.

The third category comprises wood-framing that have timber elements so degraded that they cannot be consolidated. In this case, degraded elements must be partially or totally replaced with new ones and in extreme cases of wood-framing made of very slender elements the best solution may be the total reconstruction of the window panel. There are authors that split this category in two, in terms of the partial replacement of elements being enough or there existing no option but to totally reproduce the woodframing.

The survey and appraisal of the wood-framing of the Sintra National Palace pointed out the following main anomalies (Sousa, 2003):

- degradation of paint systems;

- degradation of timber elements;

- broken glasses and cracked putty;

- defects and corrosion of ironwork;

- unsuitability concerning the following requisites:

- thermal insulation;

- protection of the furniture within;

- watertightness;

- safety against accidental actions and intrusion;

- working condition.

Generally, all the wood-framing inspected presented some degradation of the paint and in some cases of the timber itself. Degradation of the timber was usually limited to cracking, bowing and moulds, with a few cases of timber rot and in a single case a suspicion of the presence of xylophagous insects. Therefore, a systemisation of the observed anomalies was endeavoured and the degradation of the wood-framing was classified in five levels, intimately related with the necessary interventions:

- level 0 (Figure 5): wood-framing is in a good conservation state, and simple maintenance and/or cleaning works namely in ironwork at the locations of most intense circulation are enough;

- level 1 (Figure 6): wood-framing is in a good conservation state even though there is a need to clean and prepare the surface to be repainted;

- level 2 (Figure 7): wood-framing is in a reasonable conservation state; however, the painting system is already greatly degraded and therefore degraded paint needs to be scraped and new paint applied; frequently it is necessary to locally fill some joints with putty, namely those within the lower bars and cushions; 

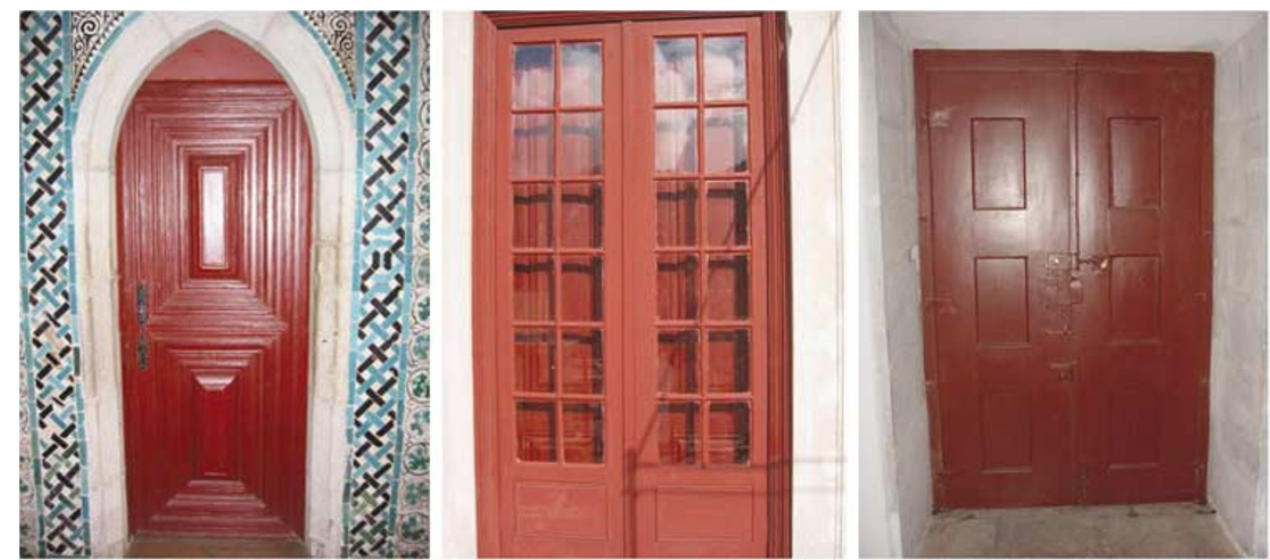

Figure 5: General aspect of wood-framing of level 0
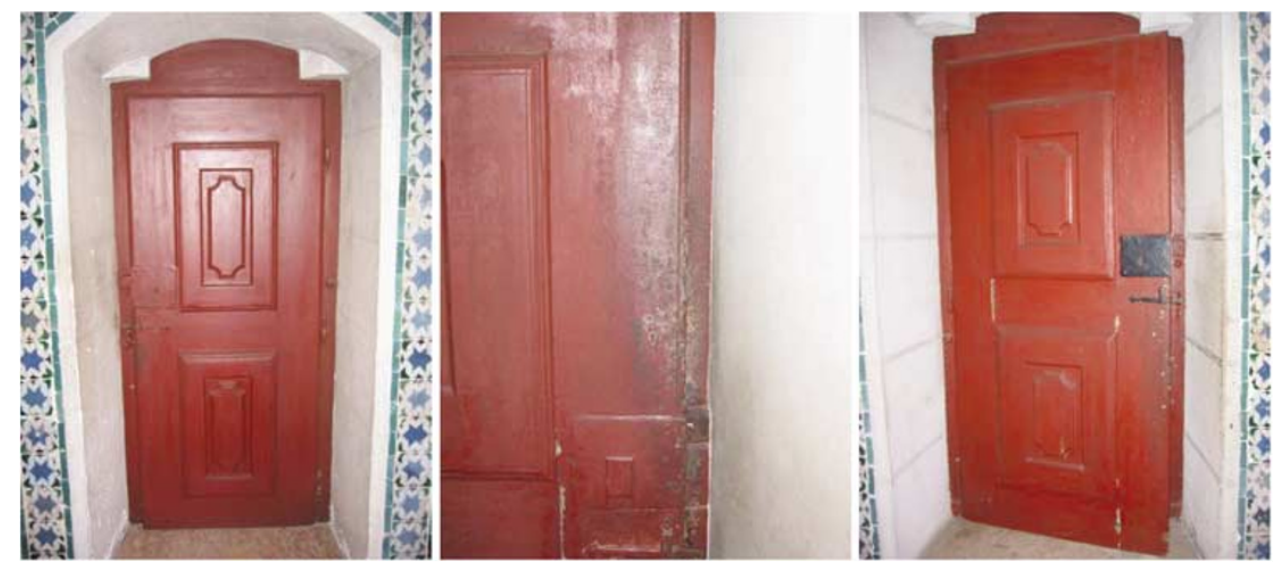

Figure 6: General aspect of wood-framing of level I

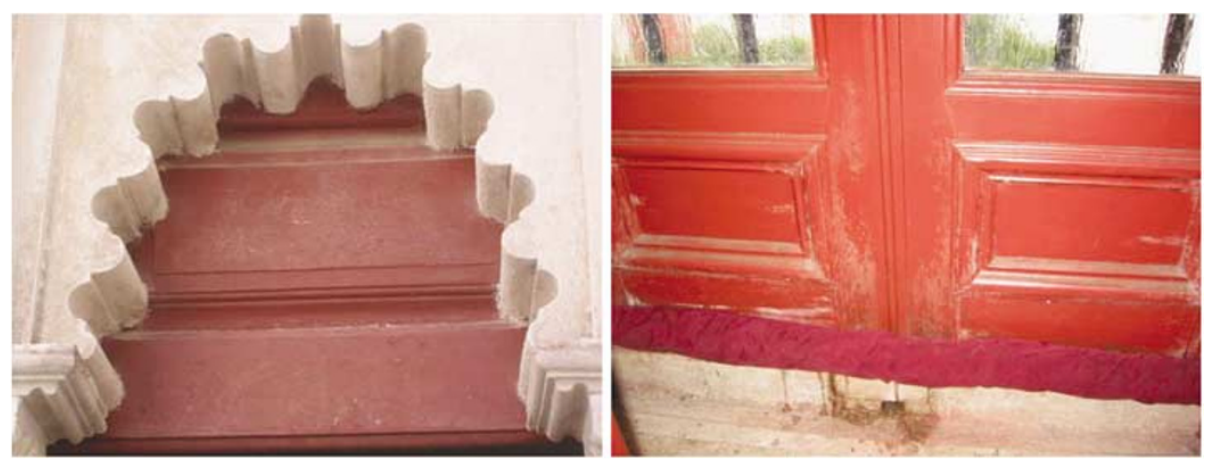

Figure 7: General aspect of wood-framing of level 2

- level 3 (Figure 8): identical to the previous one; however, the wooden surface looks irregular demanding a generalised putting of the framing before proceeding with the final painting; 

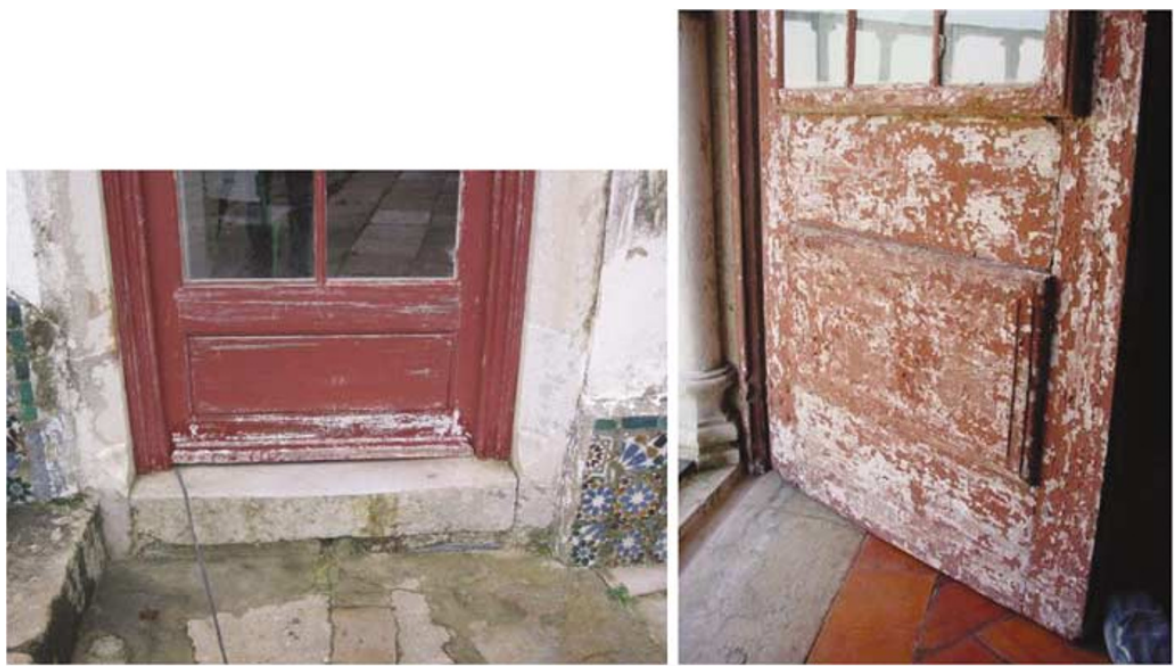

Figure 8: General aspect of wood-framing of level 3
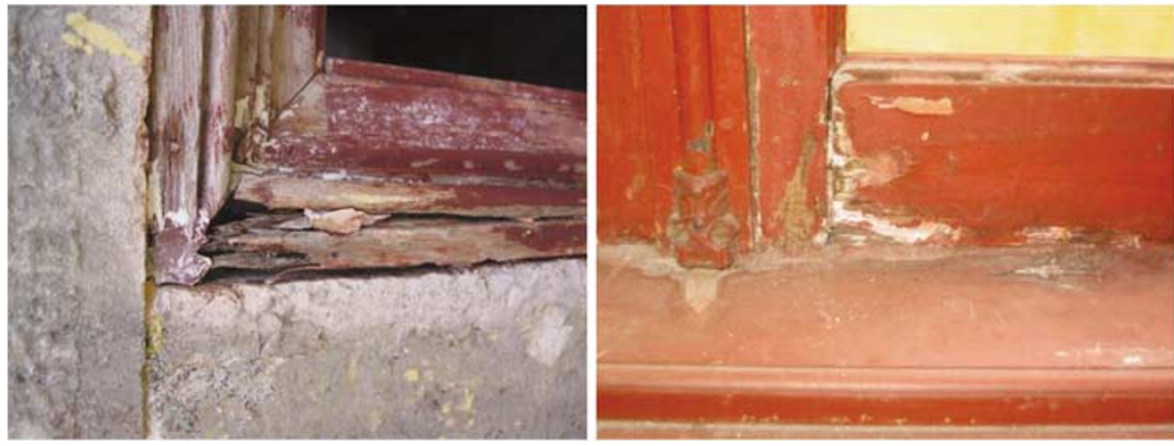

Figure 9: General aspect of wood-framing of level 4

- level 4 (Figure 9): the conservation state of the wood-framing is bad, showing degraded elements, usually the lower bars and cushions; therefore, it is necessary to replace the degraded elements before scraping, puttying and painting; in extreme cases, it is economically feasible to reconstruct the whole panel due to the extent of the degradation.

The classification presented comprehends fundamentally the anomalies concerning the degradation of the painting system, the timber elements and the glazier's putty. The remaining ones cannot be clearly included in any of these levels since (Sousa, 2003):

- in the case of broken glasses (Figure 10), their occurrence is very random and is much more a function of its location than of the degradation level; in this survey the panels with broken glasses were located mostly near trees, thus indicating that the glass had been broken by a branch, or in the tourist circuit, in which case it was broken due to accidental actions (air draughts, impacts, etc); in some cases it was registered that the glasses had been broken due to internal actions induced by the degradation and deformation of the wood-framing; 


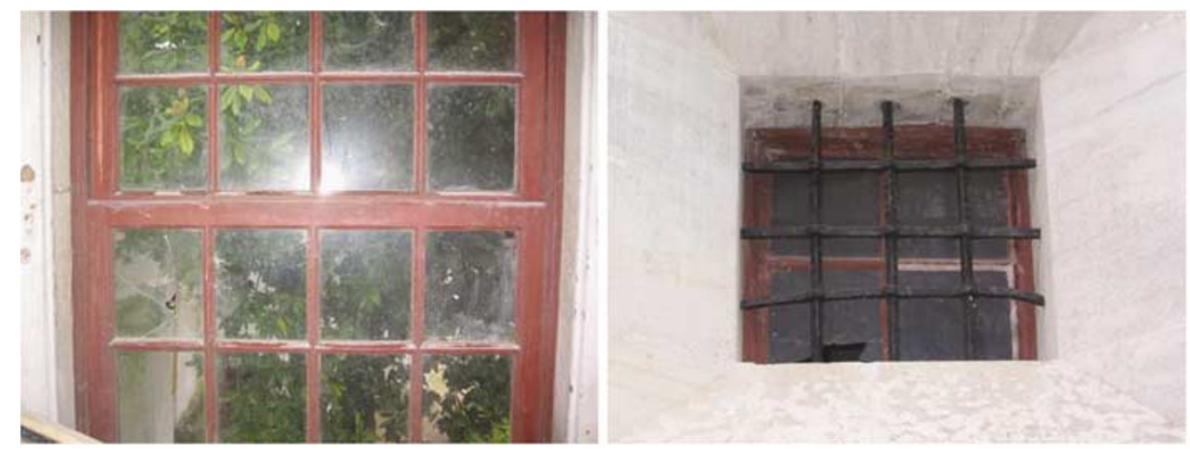

Figure 10: Examples of broken glasses

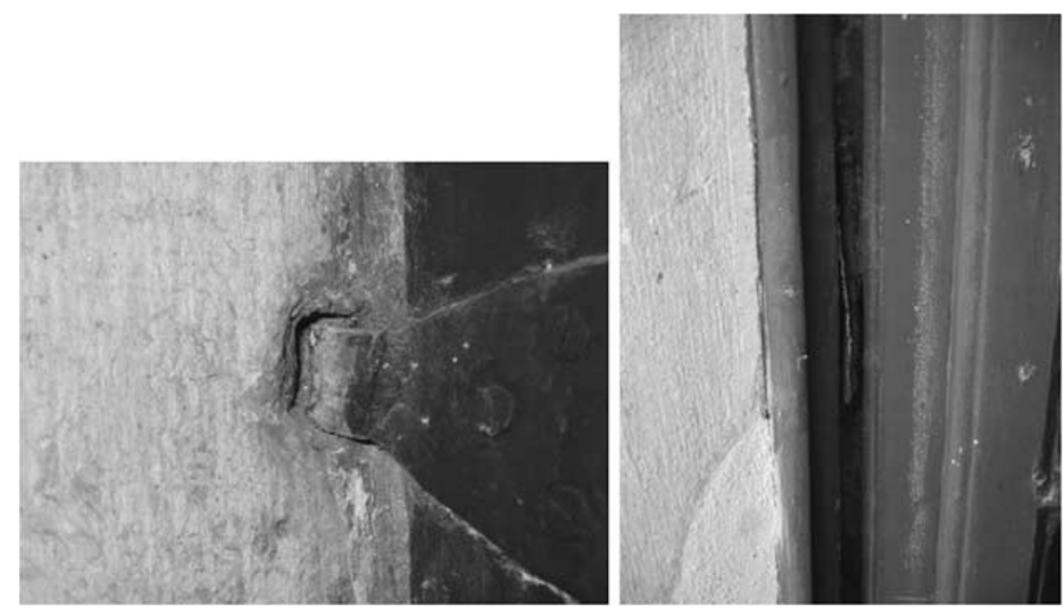

Figure I I: Examples of defects and corrosion in ironwork

- situations of defective and/or corroded ironwork (Figure 11) tended to grow in frequency from level 0 to 4 but no unequivocal relationship was found out;

- unsuitability towards certain requisites, namely thermal insulation and watertightness (Figure 12), was more or less generalised; as a matter of fact, in most panels especially near the thresholds and the window-sills the gaps were significant, causing an enormous number of hourly air renovations and the entry of rainwater in the panels most exposed to wind-driven rain; on the other hand, lack of adaptation in terms of working condition, associated with degradation of the ironwork and bowing of the wood-framing, tend to be the more frequent the higher the degradation level of the wood-framing.

In external wood-framing, due to its outer face being subjected to actions (mostly weather-wise) considerably more intense than those of the inner face, it is frequent to find different levels of degradation in the two faces, usually substantially higher in the outer face. When the degradation of the wood-framing reaches level 4 , however, this difference ceases since even though the manifestation of the anomalies may be less obvious in the inner face the timber is already structurally affected.

Based on this trend, it was possible to identify three combinations of degradation levels inner/outer face: level 1/level 2, level 1/level 3 and level 2/level 3. Furthermore, there were some situations in which the wood-framing showed a perfect conservation state in 

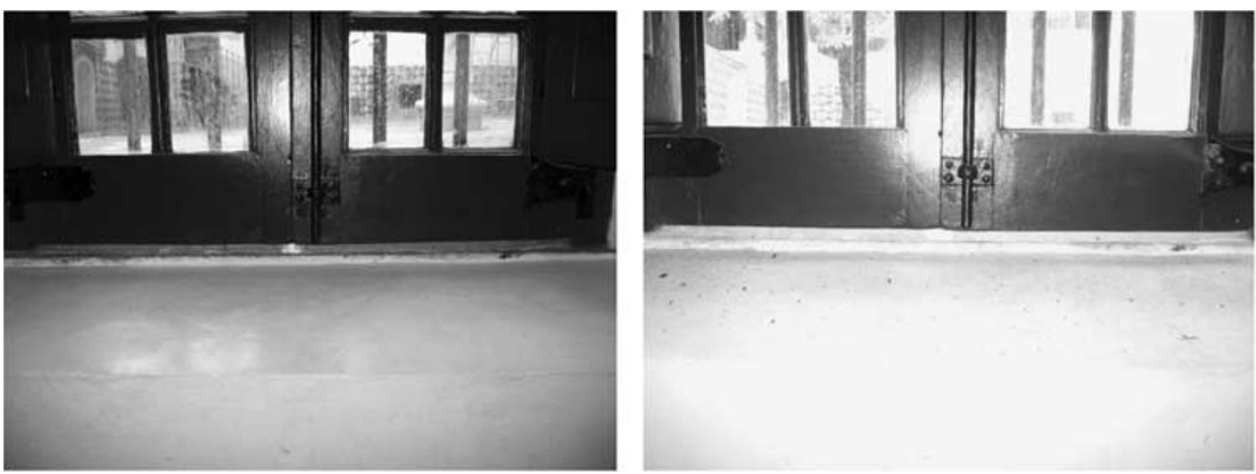

Figure 12: Unsuitability concerning requisites of thermal insulation and watertightness

the inner face, therefore excluding the need for any intervention, and various levels of degradation in the outer face.

\section{CONCLUSIONS}

A survey of the degradation state of the wood-framing of the Sintra National Palace, one of the Portuguese monuments more subjected to the effects of tourism, showed the following trends:

- A proper maintenance is able to keep a satisfactory general state of conservation and working order in elements such as wood-framing, known to be rather sensitive because of their severe exposure to weather effects and the weak intrinsic durability of the material they are made of, timber.

- Tourism, even when involving extreme levels of visitors, does not necessarily jeopardise the conservation of fragile national monuments and it certainly contributes to creating the economic conditions for a sustainable proactive maintenance strategy.

This paper is focused on a historical centuries old building but most of its content is liable to be expanded/adapted to other buildings, among them current buildings with no particular historical value. In these buildings, the main causes of degradation of woodframing apply: dampness, temperature, radiation (in regions with high solar incidence), wind, moulds and fungi (in non-ventilated locations), bacteria, xylophagous insects (whose geographical range has been increasing due to the global warming effect), normal use, vandalism and pollution.

Furthermore, the classification system proposed for wood-framing surveys, comprising five different levels, can be used in other buildings, even though unfortunately the results may be worse than the ones found in the historical building under analysis, due to its generally excellent level of maintenance.

\section{Acknowledgements}

We wish to acknowledge the support of the ICIST research centre, at Instituto Superior Técnico.

\section{References}

Aguiar, J., Cabrita, A. and Appleton, J. (1997) Guide for the Rehabilitation of Residential Buildings, Vols. 1 and 2 (in Portuguese) LNEC-DGOT, Lisbon. 
DE (Department of the Environment) (1989) Defects in Buildings, Property Services Agency (PSA). Her Majesty's Stationery Office, London.

LNEC (1967) Documentation on Construction Materials and Elements: Information on Deterioration of Materials, Files nos. 1, 2, 3 and 4 (in Portuguese), LNEC-DGOT, Lisbon.

LNEC (1968) Documentation on Construction Materials and Elements: Characteristics File - Maritime Pine (in Portuguese), LNEC-DGOT, Lisbon.

LNEC (National Laboratory of Civil Engineering) (2003) Proceedings of the 3rd Meeting on Conservation and Rehabilitation of Residential Buildings (in Portuguese), LNEC, Lisbon.

Mateus, T. (1978) Conditions of Application of Timber in Buildings in Order to Minimize the Risk of Biological Attack (in Portuguese), LNEC, Lisbon.

Morris, P.I. (1998) Understanding Biodeterioration of Wood in Structures, Forintek Canada Corporation, Québec, available from http://www.durable-wood.com/pdfs/biodeterioration.pdf, accessed 15 August 2006.

Myers, J.H. (1981) 'The repair of historic wooden windows. Preservation brief No. 9. The National Park Service. http://www.cr.nps.gov/hps/tps/briefs/brief09.htm, accessed 15 August 2006.

Nero, G. (2002) Structure and Behavior of Materials (in Portuguese). Masters in Construction Course, Instituto Superior Técnico, Lisbon.

Nunes, L. (2001) Preservation of Construction Timber. Present Situation and Future Perspectives (in Portuguese), LNEC, Lisbon.

Richardson, B.A. (1980) Remedial Treatment of Buildings, Construction Press, New York.

Richardson, B.A. (1991) Defects and Deterioration in Buildings, E \& F.N. Spon, London and New York.

Saraiva, A.C. (1957a) Fighting Hilotrupes bajulus (L.) in Urban Districts (in Portuguese), LNEC, Lisbon.

Saraiva, A.C. (1957b) Wooden Insects at the Building Site and How to Fight Them (in Portuguese), LNEC, Lisbon.

Sousa, V. (2003) The National Palace of Sintra: Non-structural Anomalies (in Portuguese), Masters Thesis, Instituto Superior Técnico, Lisbon.

Stahl, F.A. (1980) A Guide to the Maintenance, Repair and Alteration of Historic Buildings, The Construction Press Ltd, Lunesdale House, Hornsby, Lancaster, England.

Vittanen, H. (2002) Mould Growth in Painted Wood, VTT Building and Transport, Finland.

Williams, R.S. (1999) Finishing of wood in Forest Products Laboratory (USDA Forest Service), Wood handbook: wood as an engineering material (Chapter 15), available from http://www.fpl.fs.fed.us/documnts/fplgtr/fplgtr113/ch15. pdf accessed 15 august 2006 . 